On her yearly voyage to arctic waters the ship will operate under the Officer in Charge of the Eastern Arctic Patrol of the Department of Mines and Resources, who, in his capacity as chief of the expedition, will co-ordinate the activities of the various government agencies represented and maintain a general supervision of all phases of administrative activity in the Eastern Arctic.

\title{
HUDSON'S BAY COMPANY VESSELS FOR WORK IN THE CANADIAN ARCTIC
}

[Based on notes in the Arctic Circular, Vol. 2, No. 1, 1949, p. 10; Arctic. Journal of the Arctic Institute of North America, Vol. 1, No. 2, 1948, p. 119-22; and Moccasin Telegraph of September 1950 , p. 5.]

The motor-vessel Rupertsland, which was launched from the Fairfield Shipbuilding and Engineering Company yard at Glasgow on 30 November 1948 will replace the Nascopie ${ }^{1}$ for service in the Canadian Eastern Arctic. With a length of $170 \mathrm{ft}$. and a beam of $32 \mathrm{ft}$., the construction is of welded steel throughout; two 300 h.p. Diesel engines drive twin screws, housed in Kort nozzles. ${ }^{2}$ The carrying capacity of the new vessel is 500 tons, exactly half of that of her predecessor. The equipment includes radar, echo-sounder, and gyro compass. There is accommodation for twelve passengers and a crew of sixteen.

Another motor-vessel, the Fort Hearne, was built at Etherington's yard at Shelbourne, Nova Scotia, in 1949 for work in the Canadian Western Arctic. The Fort Hearne is built of wood : length, $140 \mathrm{ft}$; beam, $28 \mathrm{ft}$.; carrying capacity, 400 tons; engine, 450 h.p. Diesel. The Fort Hearne sailed from Halifax in April 1949 and reached Tuktoyaktuk (Tuktuk), where she replaced the Fort Ross, on 9 August 1949.

The motor vessel Fort Garry is an 80 -ft. ex-naval stores lighter of steel construction capable of carrying 80 tons of stores in $5 \mathrm{ft}$. of water. She was converted at Liverpool, Nova Scotia, in 1950, and will begin operations in Hudson Bay in 1951. The old Fort Severn will shortly be withdrawn from service.

\section{THE ICEBREAKER YERMAK}

[Based on a note in Pravda of 27 March 1949 and D. A. Levonevskiy, comp., S. O. Makarov $i$ zavoyevaniye Arktiki [S. O. Makarov and the conquest of the Arctic] (Leningrad, Moscow), 1043.]

In 1949 the Soviet icebreaker Yermak was awarded the Order of Lenin in celebration of her fiftieth anniversary. The Yermak owes her existence to a Russian naval officer, Vitse-Admiral S. O. Makarov, who conceived the idea of developing the small icebreaking tug, in common use for harbour clearance at the end of the nineteenth century, into something much larger and more powerful. He was thinking principally of using such a vessel in arctic waters,

1 The Nascopie was lost off Cape Dorset in July 1947. See the Polar Record, Vol. 5, Nos. $37 / 38,1949$, p. 341.

Steel tubes designed to increase the thrust of the engines when the vessel is steaming slow ahead in heavy seas or large ice fields, and to protect the propellers from ice. 
particularly for the benefit of shipping in the Kara Sea passing to and from the rivers $\mathrm{Ob}^{\prime}$ and Yenisey. Makarov had difficulty in winning approval from the Ministry of Finance, but finally he was able to place an order with Armstrong Whitworth's at Newcastle for an icebreaker of the design he had been considering. The Yermak, a vessel of 4955 gross registered tons, with a maximum displacement of 10,000 tons, was launched in 1898. Her engines, developing 10,000 h.p., drove three screws aft and one forward. Both her displacement and her engine power were more than four times greater than those of any icebreaking vessel then existing.

Tests carried out in the Gulf of Finland in 1899 were successful, but work in arctic waters brought to light several defects. For instance, the forward screw, which was an American idea found useful in the Great Lakes for helping to clear away ice fragments and for increasing manœuvrability when going astern, was too easily damaged in heavy ice. It was removed when the Yermak returned to Newcastle for modifications. Another arctic voyage was made in 1901, and this time the ship had a difficult time with ice in the northern part of the Barents Sea. Makarov had maintained that his ship would be able to steam straight to the North Pole; thus there was a certain anti-climax when it was found that some types of ice could defeat even the Yermak. Official interest in the potentialities of the ship for arctic work faded, and Makarov himself was killed in the Russo-Japanese War shortly afterwards.

The Yermak was thenceforward employed in the Baltic, mainly on routine icebreaking duties. In 1905, however, she was ordered to escort a large convoy of ships bound for the Yenisey, but she went aground at the entrance to the IKara Sea and was unable to show her worth. She did not again return to arctic waters until 1934, when her services were required under the new plan for developing a practicable Northern Sea Route. In each navigation season from 1934 to 1939 the Yermak played an important part, but her capabilities were perhaps most clearly demonstrated in 1938. The 1937 season had ended disastrously, with twenty-six ships forced to winter at sea, and the Yermak was the only icebreaker, out of the eight then serviceable, to get back to port. To her alone, therefore, fell the task of extricating the wintering ships in 1938. She did this most successfully, by herself freeing seventeen ships. In addition in February of the same year it was the Yermak which had rescued the members of the Soviet Polar Drift from their icefloe off Scoresby Sund. After the tremendous exertions of 1938 the ship had a complete refit-the first since she had been built forty years before. When Germany attacked the U.S.S.R. in 1941 the Yermak was at Leningrad and was compelled to remain there until 1945. After the war she returned to the Arctic and was still working there in 1949.

The Yermak was for many years the most powerful icebreaker in the Russian service. In 1917 she yielded this distinction to the Svyatogor (later renamed the Krasin), another Newcastle-built ship ordered by the Russian Government for the task of keeping White Sea ports open to Allied supplies. The Yermak retained second place until 1938, when the Josif Stalin, the first of four Stalin. class icebreakers, built in the Soviet Union between 1935 and 1941, came into 
commission. It says much for Makarov's original design that the Stalin-class ships incorporated many features of the Yermak. Indeed, the whole record of the Yermak is a remarkable tribute to the foresight of Makarov himself, to the ability of her designers, the skill of those who manned her, and last, but by no means least, to the British workmanship which went into her construction.

\section{A NEW GENERAL ACCOUNT OF SVALBARD}

[Review of Landet med de kalde kyster by Helge Ingstad. Oslo, Gyldendal Norsk Forlag, 1948. 422 p., illus., maps, $24 \mathrm{~cm}$. Price 32 N. Kr.]

Apart from Odd Arnesen's short account entitled Svalbardboken (Oslo, 1935) this is the first general work devoted solely to Svalbard since R. N. Rudmose Brown's Spitsbergen (London, 1920). It is tempting to compare the accounts of Ingstad and Rudmose Brown, despite the fact that there is a span of 28 years between the dates of publication. Both authors have an extensive knowledge of the archipelago, and also of other polar regions, and both wrote for a wide public. Ingstad has travelled widely in the Canadian Arctic and was Norwegian Sysselmann in East Greenland from 1932 to 1933, and in Svalbard from 1933 to 1935 , and for a short time again in 1947. Rudmose Brown, writing at the time when the sovereignty of Svalbard was under discussion, was apt to stress the importance of British explorers and British mining interests: Ingstad writing for a Norwegian public, proud of Norwegian prowess in Svalbard, is intent on emphasizing exploration, trapping and mining activity carried on by Norwegians.

Ingstad's book is divided into two main sections: the first deals with history, exploration, mining, physical features, flora and fauna; the second deals with the author's personal experiences as Sysselmann. The second is complementary to the first and the fact that this unusual combination of careful description together with personal reminiscence succeeds is a tribute to the skill of the author.

The first chapter supports the still disputed theory that Svalbard was discovered by Norwegian Vikings. Ingstad's arguments are largely based on Nansen's views although he also quotes later authorities. The title of the book itself is a translation into modern Norwegian of the Old Norse name Svalbard, "the land with the cold coasts". Most people would agree that in all probability the Vikings did visit the islands, but Ingstad fails to mention that there is still no sound proof that they did so.

The chapter on geology, geography, and the surrounding waters is very short. The geological account especially is slight, but the part dealing with hydrography and particularly ice conditions is useful. There are four chapters on animal life, one of which deals with the Polar Bear. It is in these chapters that Ingstad is thoroughly at home; he is an experienced trapper and has much of importance to say concerning conservation of stock. For this reason his chapters on the Russian and Norwegian trappers are of especial value. $\mathrm{He}$ also emphasizes the importance of the sealing and fishing in Svalbard waters. 